\title{
Making a Long Story Longer: Eastern Europe and 1968 as a Global Moment, Fifty Years Later
}

\author{
JUDIT BODNÁR
}

The article proposes an extension of the understanding of 1968 in a threefold manner: an extension of the timeframe of the events (the action in '68), a further extension to include the legacy of 1968, and a spatial-geographical expansion to make the analysis global. By elaborating on these extensions, the article considers 1968 as a global moment in which diverse histories converge and then diverge again, while the synchronicity of events generates an enhanced consciousness of the world, making the outlines of larger structures and connections more visible. Seeing 1968 in this way, the article argues, can provide a more adequate grasp on eastern Europe's '68 and its variegations.

\section{Let's Turn Hegel from His Head onto His Feet: Hopes, Myths, and Memories of the 1960s in Tamás Cseh's Musical Album “A Letter to My Sister"}

ANNA SZEMERE

This paper focuses on some salient features of the Hungarian "long sixties" through the rear-view mirror of a highly-acclaimed popular musical album by Tamas Cseh and Geza Beremenyi entitled “A Letter to My Sister" (1977). The article argues that the "Letter" owes its enduring success to its unique chronological and narrative arch: the years of childhood set in the sombrest Stalinist 1950s, while the opening up of the country's political and cultural landscape in the 1960s shaped the freedom and hope intrinsic to modern teenage life. Finally, in the portrayal of the crisis-ridden young adulthood set in the 1970s, it is impossible to set apart the failure of the "great generation" from that of Hungarian society and, more broadly, east European socialism. Implied in this narrative arch is that this local version of the "long sixties" carried the unprocessed legacy of the "short fifties."

\section{Utopias and "Normality": 1968 Revisited Fifty Years On}

\section{JACQUES RUPNIK}

The Prague Spring of 1968 did not provoke a major international crisis but at most an "incident" in the making of east-west detente. Yet it deserves to be revisited for three reasons of lasting significance for Europe. First, the Prague Spring revived, beyond the contemporary writings on Czech "democratic exceptionalism," the European debate about the relationship between socialism and democracy. Second, it was often interpreted as part of an international generational revolt against the establishments, yet it also revealed sharp contrasts between east and west. Can the misunderstandings and different legacies of 1968 in Paris and Prague be enlightening for trans-European dialogue (or lack of) after 1989? Third, Czechoslovakia in 1968 represented the most far-reaching blueprint for reforming the system within the Soviet sphere. Its crushing prevented reform in eastern Europe and Moscow. Although it provided inspiration for Gorbachev's belated, botched attempt to save the system, this was twenty years too late, thus paving the way for its implosion in 1989. 


\title{
Postmodernity's Unexpected Arrival: 1968 as Breakdown in Geoculture
}

\author{
GEORGI M. DERLUGUIAN
}

The year 1968 marked the apogee of High Modernity as expressed in the Old Left programs of either social-democratic reform or communist revolution. The New Left critics, in both east and west, demanded more of the same: a more "humane" socialism or less bureaucratic capitalism. Their demands, however, exceeded the limits of redistribution under each political system. Both western and eastern European power elites eventually found escape from state confines in globalization and neoliberalism. The exhaustion of modernity projects caused lasting fragmentation in the fields of ideology, culture, and politics previously structured by powerful national states and large political movements. This condition can be called "post-modern" in the simplest sense of following the breakdown of modernity without any new quality. The ex-Soviet countries serve as richly-nuanced examples of historical transformation from 1968 to 1989 and into the present morass.

\section{Occupy College Street: Student Radicalism in Kolkata in the Sixties}

\section{RANABIR SAMADDAR}

1968 saw a wave of protests and student radicalism in India, some of the tactics and issues of which were reminiscent of those in Europe and North America. The anti-imperialist theme was similarly strident, and the student and youth movement posed serious challenges to the old established Left, sharing traits of a global New Left agenda. The upsurge of post-independence radicalism in India, however, drew on different historical legacies, and exhibited many specific features, all of which culminated in the student and youth upsurge of 1968-69. In order to demonstrate the complex history and legacy of 60s radicalism in India, this essay takes us back to the sixties in Kolkata when the insurgent movement in West Bengal had developed the tactic of occupation, which helped the movement crystallize and caused, ironically, the undoing of the mobilization in the end. Occupy as a tactic thus has a history, and the radicals of today perhaps in their enthusiasm for the New Left ethos have ignored the history of the insurgent tactics of the past, especially tactics developed in the postcolonial context.

\section{Pluralism without Democracy, Vertical without Power: From Gorky to Nizhny Novgorod ... and Back?}

\section{ANDREY MAKARYCHEV}

This article discusses the political trajectory of the Nizhnii Novgorod region from the beginning of the 1990s until the present; from the first democratic experiences to their repudiation. The author traces the main cycles of region's political developments and defines the specificity of its political system and relations with the federal center. The article looks at the evolution of the political landscape in the region from the first post-Soviet years to mature Putinism, and then explains how political controversies are reflected in the regional identity debate. It proposes an alternative to the binary vision of the 1990s as a struggle between liberal reformists and authoritarian retrogrades, rather approaching the 1990s, with Boris El'tsin's presidency and Boris Nemtsov's governorship in Nizhnii Novgorod, as a period 
that encompassed many of the non-democratic trends that under Vladimir Putin's regime became dominant.

\title{
Inside Russia's Imperial Relations: The Social Constitution of Putin-Kadyrov Patronage
}

\author{
JULIE WILHELMSEN
}

This article analyzes how Moscow has extended its rule over Chechnia since the beginning of this century. Within the larger understanding of this rule as imperial in form, the current distinct contractual relationship between the Russian center and Chechnia is substantiated as one based on kinship. I argue that the Putin-Kadyrov relationship is a generic case of patronage but highlight the local imprint that such relations acquire by tracing how Chechen kinship practices inform this case.

\section{Kant's Future: Debates about the Identity of Kaliningrad Oblast}

\section{MiŁOSZ J. ZIELIŃSKI}

This article addresses the role that the legacy of the pre- and post-WWII past has played in ongoing identity debates among the inhabitants of Kaliningrad oblast of the Russian Federation. Since 1991, interest in preserving this legacy has been on the rise, influencing the inhabitants' feeling of regional distinctiveness in numerous ways. While the pre-war legacy is important for a considerable number of Kaliningraders, others believe that it threatens the Russian and Soviet mien of the Oblast, both in cultural and political terms. They favor taking greater care of Soviet-era buildings, monuments, and other commemorations of war heroes. This viewpoint disparity has recently widened due to both internal and external factors, including the deterioration of Russo-western relations. A March 2015 incident in the village of Veselovka is used to reflect upon the way in which pre-war and post-war legacies are used in the above-mentioned identity debate. The author examines the direction of identity construction in the oblast through the officially-acknowledged vision of Russianness as pursued by President Vladimir Putin, in particular, and the Russian government, in general.

\section{Affirmative Action in the Western Borderlands of the Late Russian Empire?}

\section{DARIUS STALIŪNAS}

This article argues that apart from a couple of cases, there were no situations where the Russian imperial government would have supported Lithuanian national culture as a counterbalance against Poles, and more generally, that the policy of "divide and rule" was in principle not applied on the empire's western periphery regarding other non-dominant ethnic groups. A more general reason for not implementing such a policy was related to many officials' belief that the government should seek integration, acculturation, or even assimilation of non-Russian ethnicities. At the same time, on the Russian mental map, the Northwest Region was understood not just as part of the empire, but as part of Russian national territory. In such a territory, most of the government subscribed to a discourse of nationalism that permitted no means of support for the strengthening of non-Russian nationalisms. Finally, social radicalism of the Lithuanian, Latvian, or Estonian national movements was another obstacle for tsarist officials to support these "peasant" nationalities. 


\title{
Russia's Post-Soviet Ideological Terrain: Zvyagintsev's Leviathan and Debates on Authority, Agency and Authenticity
}

\author{
Susanne Wengle, Christy Monet and Evgenia Olimpieva
}

Much of the literature on post-Soviet ideology interprets ideology as the content of state-sponsored doctrines or measures it via persistent strands in public opinion. This paper relies on a different notion: we think of societal and state perspectives as engaged with each other in a contentious dialogue that is constitutive of ideology. With this dialogic conception of ideology, this paper provides a map of Russia's ideological terrain through an analysis of the debates surrounding Andrey Zvyagintsev's 2014 film Leviathan. We show that the film and the debates it provoked engaged with state-sponsored narratives and highlight three key themes of ideational contestation in contemporary Russian politics: authority, agency, and authenticity. An examination of these ideational battles in which provocative and resonant societal critiques challenge dominant narratives provides an original account of ideology in contemporary Russia. It also speaks to debates on civil society that have increasingly become interested in ideational politics. 